\title{
Teenage pregnancy - A Socio-demographic study at a Rural Medical College Hospital in Southern India
}

\author{
Indranil Dutta1, Nidhi Jha², Dilip Kumar Dutta ${ }^{3}$ \\ ${ }^{1}$ IQ City Medical College, Durgapur, West Bengal, ${ }^{2}$ AIMS, Bellur, Karnataka, ${ }^{3}$ GICE Hospital, Kalyani, West Bengal
}

\section{A B S TRA C T}

Aim: This study is aimed to analyze the socio-demographic factors of teenage pregnancy compared to adult pregnancies. Method: A Hospital based prospective study of all teenage pregnant females admitted to Rural Medical College Hospital in Karnataka. Data was collected by detailed history taking and following up the patient from admission till delivery by using a proforma devised for the study. For each teenage two simultaneous adults primigravidas were studied. Result: Most of teenage mothers (53.5\%) haven't had primary education itself compared to $8.1 \%$ in adults. In the present study, majority of the population $47.5 \%$ in teenage and $72.5 \%$ in adults belonged to middle socioeconomic class (upper and lower) and $43.75 \%$ of teenage belong to low socioeconomic class compared to $15 \%$ of adults. In my study $98 \%$ of the population belonged to rural area. $61.25 \%$ of teenage mothers were booked. In present study the TT Immunization was adequate for both the groups. Conclusion: Teenage pregnancy is still a huge problem in India mainly related to early menarche, early age at marriage, low education, unemployment, joint family structure, lack of antenatal care. The problem of teenage pregnancy cannot be removed instead focus can be diverted towards reducing chances of early pregnancy which can be difficult for a teenage girl.

Key words: Teenage pregnancy, Socio demographic factors, Antenatal care
Access this article online

Website:

http://nepjol.info/index.php/AJMS

\section{INTRODUCTION}

Teenage Pregnancy is a huge problem in developed as well as developing countries. Pregnancy can result in lot of hardship for the women including various health conditions, poor living habit, huge burden of child upbringing can itself cause lot of damage to the teenage mother's psychology. Pregnancy can occur around 12 or 13 , and being the stage at which a female becomes potentially fertile. National Family Health Survey (NFHS)-3 revealed that $16 \%$ of women, aged $15-19$ years, have already started childbearing. In rural regions, the rate is much higher that is $21.21 \%{ }^{1}$ than it is in urbanized areas. Studies done in various parts of the countries such as Bombay showed a rate of $33.17 \%,{ }^{2}$ Kolkata $15.7 \%,{ }^{3}$ Madurai $13.1 \%,{ }^{4}$ Hyderabad 5.1\%, ${ }^{5}$ and Coimbatore 12.69\%. ${ }^{6}$

In developed regions, teenage mothers tend to be unmarried, and adolescent pregnancy is seen as a social issue whereas, in developing countries, such pregnancies mostly occur in married teenagers, and their pregnancy is most often welcomed by family and society. ${ }^{7,8}$

It was reported by Smitha et al. ${ }^{9}$ that most teenage pregnancies occur in the lower socioeconomic group, especially the unmarried with increasing sexual freedom, teenage pregnancies are increasing in the higher socioeconomic group also, but the rate of abortion in this group is high.

Data from National longitudinal study of youth (1994) indicate that one quarter of teenage mothers have a second child within 24 months of their first birth.

Thirteen out of 14 were socially excluded, $50 \%$ had disclosed domestic violence (compared with $12 \%$ of the entire cohort of mothers who died) and 50\% were poor attendees at antenatal clinic (compared with $20 \%$ of the total cohort who were poor attendees or booked late). 
The correlation between deprivation and maternal deaths was also seen in the subsequent report, 2000-2002. ${ }^{10}$

Teenage pregnancy has also been associated with an increased prevalence of domestic violence. However, a recent review of 15 studies has failed to clarify whether there is a causal link between maltreatment or violence and adolescent pregnancy or whether there is an increased risk of domestic violence to pregnant teenagers. ${ }^{11}$

At present the incidence in England and Wales is in between 2-44 per $1000 .^{12}$

Spitz et al. ${ }^{13}$ had noted that teenage pregnancy rate is considerably higher in USA with the incidence varying from 25-75 per 1000 for 15-17 years and 92-165 per 1000 for 18-19 years.

Regarding the problem of low education - Wellings et al. ${ }^{14}$ surveyed over 11,000 males and females aged 16-44 years across the UK. They found that 29\% of sexually active young women who left school at 16 years of age without any qualifications had a child before the age of 18 years, compared with $14 \%$ of those who left at 16 with qualifications and $1 \%$ of those who left at age 17 years or over.

This study aimed to find out the incidence and to analyze the socio demographic factors of teenage pregnancy.

\section{MATERIALS AND METHODS}

A clinical prospective case control study was done from $1^{\text {st }}$ November 2010 to $30^{\text {th }}$ December 2012 in Department of Obstetrics and Gynecology in a Rural Medical College in Karnataka, Ethical clearance was obtained, Consent was taken from patients. All Teenage Primigravidas were taken for the study group and Adult Primigravidas were control group. For each Teenage Patients simultaneous two adults were studied and demographic variables were noted. P-value was calculated for statistical significance. In this study 80 teenage patients were taken compared to 160 adults for analysis.

\section{RESULTS}

\begin{tabular}{lcc}
$\begin{array}{l}\text { Table 1: Age distribution of patients studied } \\
\text { (teenage group) }\end{array}$ \\
\hline Age in years (teenage primigravida) & Number of patients & $\%$ \\
\hline$\leq 15$ years & 0 & 0.0 \\
$16-17$ years & 2 & 2.5 \\
18 years & 28 & 35.0 \\
19 years & 50 & 62.5 \\
Total & 80 & 100.0 \\
\hline Mean $\pm S D: 18.60 \pm 0.54 ;$ Majority of study population were 19 years $(62.5 \%)$
\end{tabular}

$\begin{aligned} & \text { Table 2: Age distribution of patients studied } \\
& \text { (Adults group) }\end{aligned}$
\begin{tabular}{lcc}
\hline Age in years (adult primigravida) & Number of patients & $\%$ \\
\hline $20-21$ years & 68 & 42.5 \\
$22-24$ years & 68 & 42.5 \\
$25-27$ years & 20 & 12.5 \\
$28-29$ years & 4 & 2.5 \\
$>30$ years & 0 & 0.0 \\
Total & 160 & 100.0 \\
\hline Mean \pm SD: $22.21 \pm 2.05 ;$ Majority of study group were of age $20-24$ years that is $85 \%$
\end{tabular}

\begin{tabular}{lcccccc} 
Table 3: Marital status & & \\
\hline & \multicolumn{2}{c}{ Teenage } & & \multicolumn{3}{c}{ Adult } \\
\cline { 2 - 3 } \cline { 5 - 6 } & No & $\%$ & & No & $\%$ \\
\hline Married & 80 & 100 & & 160 & 100 \\
Unmarried & - & - & & - & - \\
\hline
\end{tabular}

All of the study population were married. This highlights the incidence of teenage marriages in India

\begin{tabular}{lcc} 
Table 4: Age at marriage: Teenage & \\
\hline Age & Number & $\%$ \\
\hline$\leq 15$ & - & - \\
$16-17$ & 12 & $15 \%$ \\
18 & 26 & $32.5 \%$ \\
19 & 42 & $52.5 \%$
\end{tabular}

Mean age of marriage is 18 years. $47.5 \%$ of population was married by 18 years of which $15 \%$ were below 18 years

\begin{tabular}{lcc}
\hline Table 5: Age at marriage: Adults \\
\hline Age & Number & $\%$ \\
\hline$\leq 20$ & 40 & $25 \%$ \\
$20-21$ & 66 & 41.25 \\
$22-24$ & 46 & 28.75 \\
$25-27$ & 8 & 5 \\
$28-29$ & - & - \\
\hline
\end{tabular}

\begin{tabular}{lcc}
$\begin{array}{l}\text { Table 6: Interval between menarche and } \\
\text { marriage: Teenage }\end{array}$ \\
\hline Interval years & Number & $\%$ \\
\hline$\leq 1$ & 2 & 2.5 \\
2 & 6 & 7.5 \\
3 & 8 & 10 \\
4 & 26 & 32.5 \\
$\geq 5$ & 38 & 47.5 \\
\hline
\end{tabular}

$52.5 \%$ of teenagers were married $\leq 4$ years of menarche, low gynecological age was seen ( $\leq 2$ years) in $10 \%$ of the population

\begin{tabular}{lcc}
$\begin{array}{l}\text { Table 7: Interval between menarche and } \\
\text { marriage: Adults }\end{array}$ \\
\hline Interval years & Number & $\%$ \\
\hline $1-3$ & - & - \\
$4-6$ & 60 & 37.5 \\
$7-10$ & 72 & 45 \\
$\geq 10$ & 28 & 17.5 \\
\hline
\end{tabular}

Asian Journal of Medical Sciences | Oct-Dec 2014 | Vol 5 | Issue 4 


\begin{tabular}{lccllc}
\multicolumn{2}{l}{ Table 8: Consanguinity } \\
\cline { 1 - 2 } Consanguinity & \multicolumn{2}{c}{$\begin{array}{c}\text { Teenage } \\
\text { primigravida }\end{array}$} & & \multicolumn{2}{c}{$\begin{array}{c}\text { Adult } \\
\text { primigravida }\end{array}$} \\
\cline { 2 - 3 } \cline { 6 - 7 } & No & $\%$ & & No & $\%$ \\
\hline First degree & - & - & & - & - \\
Second degree & 7 & 8.75 & & 3 & 1.88 \\
Third degree & - & - & & - & - \\
Non consanguineous & 73 & 91.25 & & 157 & 98.12 \\
\hline Non-consanguinity were similar in both groups & & &
\end{tabular}

\begin{tabular}{lccccc} 
Table 9: Education distribution of patients studied \\
\hline Education & \multicolumn{2}{c}{$\begin{array}{c}\text { Teenage } \\
\text { primigravida }\end{array}$} & & \multicolumn{2}{c}{$\begin{array}{c}\text { Adult } \\
\text { primigravida }\end{array}$} \\
\cline { 2 - 3 } \cline { 5 - 6 } & No & $\%$ & & No & $\%$ \\
\hline No schooling & 43 & 53.5 & & 13 & 8.1 \\
Primary & 10 & 12.5 & & 11 & 6.9 \\
Secondary & 18 & 22.5 & & 19 & 11.9 \\
High school & 9 & 11.3 & & 77 & 48.1 \\
PUC & 0 & 0.0 & & 31 & 19.4 \\
Graduate & 0 & 0.0 & & 5 & 3.1 \\
Total & 80 & 100.0 & & 160 & 100.0 \\
\hline PU: & 0 & &
\end{tabular}

PUC: Pre University Course $53.5 \%$ of Teenage primigravida group were illiterate compared to adults 20-29 years with $P<0.001^{* *}$. More number of adults were educated compared to teenage

\begin{tabular}{|c|c|c|c|c|}
\hline \multirow[t]{2}{*}{ Religion } & \multicolumn{2}{|c|}{$\begin{array}{c}\text { Teenage } \\
\text { primigravida }\end{array}$} & \multicolumn{2}{|c|}{$\begin{array}{c}\text { Adult } \\
\text { primigravida }\end{array}$} \\
\hline & No & $\%$ & No & $\%$ \\
\hline Hindu & 79 & 98.5 & 158 & 98.5 \\
\hline Muslim & 1 & 1.5 & 2 & 1.5 \\
\hline Total & 80 & 100.0 & 160 & 100.0 \\
\hline
\end{tabular}

\begin{tabular}{|c|c|c|c|c|}
\hline Employment & Teenage & Percentage \% & Adults & Percentage $\%$ \\
\hline Unemployed & 74 & 92.5 & 68 & 42.5 \\
\hline Employed & 6 & 7.5 & 92 & 57.5 \\
\hline Total & 80 & 100 & 160 & 100 \\
\hline \multicolumn{5}{|c|}{$\begin{array}{l}\text { Majority of Teenagers were unemployed ( } 92.5 \%) \text { compared to } 42.5 \% \text { of adults. } \\
\text { Teenage pregnancy further reduces employment status and makes them } \\
\text { economically dependent on their family }\end{array}$} \\
\hline
\end{tabular}

\begin{tabular}{lcccc}
\multicolumn{5}{l}{ Table 12: Family distribution according to type } \\
\hline Type of family & Teenage & Percentage & Adults & Percentage \\
\hline Joint family & 59 & 73.75 & 124 & 77.5 \\
Nuclear family & 21 & 26.25 & 36 & 22.5 \\
Total & 80 & 100 & 160 & 100 \\
\hline
\end{tabular}

Staying in a joint family influences the Teenager's own decision and so is elicited in majority of the cases

\begin{tabular}{|c|c|c|c|c|}
\hline \multirow[t]{2}{*}{$\begin{array}{l}\text { Socio-economic } \\
\text { status }\end{array}$} & \multicolumn{2}{|c|}{$\begin{array}{c}\text { Teenage } \\
\text { primigravida }(n=80)\end{array}$} & \multicolumn{2}{|c|}{$\begin{array}{c}\text { Adult } \\
\text { primigravida }(n=160)\end{array}$} \\
\hline & No & $\%$ & No & $\%$ \\
\hline Upper high & 2 & 2.5 & 8 & 5 \\
\hline Higher & 5 & 6.25 & 12 & 7.5 \\
\hline Upper middle & 10 & 12.5 & 40 & 25 \\
\hline Lower middle & 28 & 35 & 76 & 47.5 \\
\hline Poor & 30 & 37.5 & 20 & 12.5 \\
\hline Very poor & 5 & 6.25 & 4 & 2.5 \\
\hline Total & 80 & 100 & 160 & 100 \\
\hline
\end{tabular}

\begin{tabular}{lccccc}
$\begin{array}{l}\text { Table 14: Antenatal care distribution of patients } \\
\text { studied }\end{array}$ \\
\cline { 1 - 3 } $\begin{array}{l}\text { Antenatal } \\
\text { care }\end{array}$ & $\begin{array}{c}\text { Teenage primigravida } \\
(\mathbf{n = 8 0 )}\end{array}$ & & \multicolumn{2}{c}{$\begin{array}{c}\text { Adult primigravida } \\
(\mathbf{n = 1 6 0 )}\end{array}$} \\
\cline { 2 - 3 } \cline { 5 - 6 } & No & $\%$ & & No & $\%$ \\
\hline Booked & 49 & 61.25 & & 149 & 93.1 \\
Unbooked & 31 & 38.75 & & 11 & 6.9 \\
Total & 80 & 100.0 & & 160 & 100.0 \\
\hline
\end{tabular}

Unbooked cases are significantly more in teenage primigravida group with $\mathrm{P}<0.001^{* *}$ compared to adults

\begin{tabular}{|c|c|c|c|c|}
\hline \multirow[t]{2}{*}{ Immunization } & \multicolumn{2}{|c|}{$\begin{array}{l}\text { Teenage primigravida } \\
\qquad(n=80)\end{array}$} & \multicolumn{2}{|c|}{$\begin{array}{l}\text { Adult primigravida } \\
\qquad(n=160)\end{array}$} \\
\hline & No & $\%$ & No & $\%$ \\
\hline Yes & 80 & 100.0 & 159 & 99.3 \\
\hline No & 0 & 0.0 & 1 & 0.7 \\
\hline Total & 80 & 100.0 & 160 & 100.0 \\
\hline
\end{tabular}

\section{DISCUSSION}

Present study was carried out in Rural medical College and Hospital in Karnataka. This study was undertaken to understand the factors contributing for pregnancy among teenage mothers and their socio demographic factors which are responsible.

\section{Age of the study}

In this present study youngest mother was of 17 years. Most mothers belonged to 19 years $(62.5 \%)$. In adult primigravida commonest age group is between $20-24$ years $(85 \%)$.

\section{Marital status}

The proportion of unmarried and married people as given by many authors are as follows. 


Table 16: Comparison of marital status with
respect to other studies
\begin{tabular}{llcc}
\hline SI.No. & Study & Unmarried & Married \\
\hline 1 & Kavita N Singh et al., 200115 & $11.6 \%$ & $88.4 \%$ \\
2 & Sharma AK et al., $2003^{16}$ & - & $100.0 \%$ \\
3 & Ashok Kumar, $2007^{17}$ & - & $100.0 \%$ \\
4 & Present study & - & $100.0 \%$ \\
\hline All of our study population was married comparable to above studies
\end{tabular}

\section{Age at marriage}

Table 17: Comparison of mean age with respect
to other studies

One of the most important factors are determining the age at which the first pregnancy occurs. In India, although the legal age at marriage is 18 for females and 21 for males, early marriage continues to be the norm. Centre for Development and Population Activities revealed that the average age at marriage among rural teenager was 16 as compared to urban areas i.e. 18.7 in INDIA, In Nepal it is 16 years, in our study it is 17.4 years.

\section{Menarche - marriage interval}

The interval between menarche and marriage in our study is that $52.5 \%$ of teenage primigravidae got married within 4 years of menarche compared to $37.5 \%$ for adults.

\section{Consanguinity}

Majority of both groups had non consanguinous marriage.

\section{Illiteracy}

Present study highlights, majority of patients were of low socio-economic status in both study and control group. This is mostly due to poor educational status in the teenage mothers. Most of teenage mothers (53.5\%) haven't had primary education itself compared to $8.1 \%$ in adults.

\section{Socio-economic status}

In the present study, majority of the population $47.5 \%$ in teenage and $72.5 \%$ in adults belonged to middle socioeconomic class (upper and lower) and $43.75 \%$ of teenage belong to low socioeconomic class compared to $15 \%$ of adults.

\section{Area}

In my study $98 \%$ of the population belonged to rural area. A study by Kavita N Singh et al. (2001) ${ }^{15}$ showed that $65.3 \%$ of population was from urban and $44.7 \%$ from rural areas.

\section{Antenatal care}

\begin{tabular}{|c|c|c|}
\hline Authors & Booking & \\
\hline Sharma AK, $2003^{16}$ & $20.7 \%$ & \\
\hline Ashok Kumar, $2007^{17}$ & $52.7 \%$ & \\
\hline Present study & Teenage $=61.25 \%$ & Adult $=93.1 \%$ \\
\hline
\end{tabular}

$61.25 \%$ of teenage mothers were booked. All the teenage women in our study were immunized inspite of $38.75 \%$ being unbooked cases. Only one adult was not immunized and was an unbooked case. Awareness were mostly due to our government programmes hence booked cases in our study was little higher compared to other studies.

Proper antenatal care has a positive influence on the health of the mother and child. Teenagers do not take Iron-Folic acid (IFA) tablets properly and fewer are fully immunized with tetanus toxoid than mature women. But In present study the TT Immunization was adequate for both the groups.

\section{CONCLUSION}

From the present study it throws a light on various socio demographic factors relating to teenage pregnancy. Such factors if detected early can reduce significant number of complications including anemia, pre-eclampsia and preterm labour etc and also reduces higher operative interference, higher rate of LSCS followed by higher number of NICU admissions.

Since teenage pregnancy is a multifaceted problem, it demands multidimensional solutions. Pregnancy itself has a tremendous effect on teenage and her family. Here it was seen that teenage pregnancy was more common in low socio-economic status, due to lack of education, awareness of complications of teenage pregnancy. So this indicates, that awareness regarding teenage pregnancy, sex education and access to effective contraception are essential to improve social, psychological and mental status of teenage mother.

\section{REFERENCES}

1. Goswami BK and Goswami BJ. Teenage Pregnancy. Obstet Gynaec India 1989; 39: 475-478.

2. Pratinidhi A, Shrotri A and Shah U. Risk of teen-age pregnancy in a rural community of India. Indian J Matern Child Health 1990; 1(4):134-138.

3. Banerjee B, Pandey GK, Dutt D, Sengupta B and Mondal M. Teenage Pregnancy: A socially inflicted health hazard. Indian J Community Med 2009; 34: 227-231.

4. Philips PS and Siva Kama Sundar. Teenage pregnancy. J Obstet Gynaec India 1978; 28: 576-81. 
5. Pachauri S, Jamshedji A. Risk of teenage pregnancy. J Obstet and Gynecol India 1933; 33: 477-4781.

6. Seeniammal. Problem of teenage pregnancy: Handbook 1983: 125-36.

7. Mayor S. Pregnancy and childbirth are leading causes of death in teenage girls in developing countries. BMJ 2004; 328: 1152-1153.

8. Agarwal $\mathrm{N}$ and Reddaiah VP. Factors affecting birth weight in a suburban community. Health Popul Perspect Issue 2005; 28 : 189-196.

9. Smitha T. Influence of socio-economic factors on attaining targets for reducing teenage pregnancies. BMJ 1993; 206(6887):12321235.

10. The Sixth Report of the Confidential Enquiries into Maternal Deaths in the United Kingdom. Confidential Enquiry into Maternal and Child Health, Why Mothers Die 2000-2002; 2004.

11. Blinn-Pike L, Berger T, Dixon D, Kuschel $D$ and Kaplan M. Is there a causal link between maltreatment and adolescent pregnancy?
A literature Review. Perspect Sex Reprod Health 2002; 34:68-75.

12. Teenage Pregnancy in Britain Birth Control Trust. London Bury. British Journal of Obstet Gynaecol 1985; 92: 1081-1083.

13. Spitz AM and Ventera SJ. Surveillance for pregnancy and birth rates among teenagers by state - United States. Adolescent Health 1993; 42(6):1-27.

14. Wellings K, Nanchahal K, Macdowall W, McManus S, Erens B, Mercer $\mathrm{CH}$, et al. Sexual behaviour in Britain: early heterosexual experience. Lancet 2001; 358:1843-1850.

15. Kavitha N Singh. Outcome of adolescent pregnancy. Journal of Obstetrics and Gynaecology of India 2001; 51(6):34-36.

16. Sharma AK, Chhabra P, Pushpa Gupta and Lyngdoh T. Pregnancy in adolescents, a community based study. Indian J Prev Soc Med 2003; 34(1):24-26.

17. Ashok Kumar, Tej Singh, Sriparna Basu and Sulekha Pandey. Outcome of Teenage Pregnancy. Indian Journal of Pediatrics 2007; 74(10): 927-931.

\section{Authors Contribution:}

ID - Designed the study, collected data and correlated the results; NJ - Collected the cases; DKD - Supervised the study.

Source of Support: Nil, Conflict of Interest: None declared. 